\title{
THE IMPORTANCE OF POTASSIUM CHANNELS IN THE MECHANISM OF THE RELAXING EFFECT OF PENTOXIFYLLINE ON ISOLATED RAT UTERI
}

Slobodan R. Milovanovic ${ }^{1}$, Jelena Kordic-Bojinovic ${ }^{2}$, Stevanka Djordjevic ${ }^{1}$, Dragana Drakul ${ }^{1}$, Dragana Sokolovic ${ }^{1}$, Natasa Miletic ${ }^{1}$ and Dusko Blagojevic ${ }^{3}$ ${ }^{1}$ Department of Pharmacology, Toxicology and Clinical Pharmacology, Faculty of Medicine, University of East Sarajevo, Foca, Republic of Srpska, Bosnia and Herzegovina ${ }^{2}$ High Medical School "Milutin Milankovic", Belgrade, Serbia

${ }^{3}$ Department of Physiology, Institute for Biological Research "Sinisa Stankovic", University of Belgrade, Belgrade, Serbia

\section{VAŽNOST RASTUĆIH KONCENTRACIJA PENTOKSIFILINA NA KONTRAKTILNOST IZOLOVANOG UTERUSA PACOVA U PRISUSTVU BLOKATORA KALIJUMSKIH KANALA}

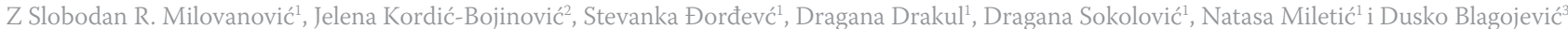 \\ ${ }^{1}$ Odsek za farmakologiju, toksikologiju i kliničku farmakologiju, Medicinski fakultet, \\ Univerzitet u Istočnom Sarajevu, Foča, Republika Srpska, Bosna i Hercegovina \\ ${ }^{2}$ Visoka medicinska škola“Milutin Milanković”, Beograd, Srbija \\ ${ }^{3}$ Odsek za fiziologiju, Institut za biološka istraživanja "Siniša Stanković", Univerzitet u Beogradu, Beograd, Srbija
}

\section{ABSTRACT}

Background. Pentoxifylline is a methylxanthine derivative that is used to treat peripheral vascular disease. One of the mechanisms of action of pentoxifylline is the vasodilatation of blood vessels. This study examined the effect of increasing pentoxifylline concentrations on the contractility of isolated rat uteri in the presence of a potassium channel antagonist.

Methods. The uteri were isolated from virgin Wistar rats (180-220 g) and suspended in an isolated organ bath chamber containing De Jalon's solution and aerated with 95\% $\mathrm{O}_{2}$ and $5 \% \mathrm{CO}_{2}$. The temperature was maintained at $37^{\circ} \mathrm{C}$. Isometric contractions were recorded using an isometric force transducer (Ugo Basile). The preload of the preparation was approximately $1 \mathrm{~g}$. The uteri were allowed to contract spontaneously or in the presence of $\mathrm{Ca}^{2+}(0.018$ and $0.36 \mathrm{mM})$ and acetylcholine (ACh) and were treated with pentoxifylline.

Results. Pentoxifylline caused concentration-dependent inhibition of spontaneous rhythmic uterine activity and uterine activity caused by calcium $\mathrm{Ca}^{2+}(0.018 \mathrm{mM}$ and $0,36 \mathrm{mM})$. We showed that the inhibitory effects of pentoxifylline depend on the type of muscle contractions activated and that the inhibitory effect is significantly stronger for spontaneous rhythmic activity and forin $\mathrm{Ca}^{2}$-induced contractions of isolated rat uteri+. The relaxing effect of pentoxifylline depends on the calcium concentration in the medium. Pentoxifylline exerted the weakest relaxant effects on contractions induced by acetylcholine. In contrast to methylene blue, tetraethylammonium, or 4-aminopyridine, glibenclamide did not antagonise the relaxing effect of pentoxifylline on isolated rat uteri..

Conclusion. The results obtained suggest that the mechanism of action of pentoxifylline does not lead to the opening of $K_{A T P}$ channels. However, the opening of BKCa and voltage-dependent $\mathrm{Ca}^{2+}$ channels had some role, but to varying degrees, in the mechanism of the relaxing effect of pentoxifylline on the spontaneous rhythmic activity and calcium-induced con-

\section{SAŽETAK}

Cilj. Pentoksifilin, koji se koristi za lečenje perifernih vaskularnih oboljenja, je derivat metilksantina. Jedan od načina delovanja pentoksifilina je prouzrokovanje vazodilatacije krvnih sudova. U ovom radu ispitivali smo efekat rastuciih koncentracija pentoksifilina na kontraktilnost izolovanog uterusa pacova, u prisustvu blokatora kalijumskih kanala.

Metode. Uterusi, koji su izolovani od neparenih ženki pacova Wistar soja (180-220 g), držani su u kupatilu za izolovane organe na temperaturi od $37^{\circ} \mathrm{C}$, u De Jalon-ovom rastvoru kroz koji je propuštana smeša gasova od 95\% kiseonika $i$ 5\% ugljendioksida. Izometrijske kontrakcije su registrovane korišćenjem izometrijskog transdjusera Ugo Basile, pri opterećenju preparata od $1 \mathrm{~g}$. Ispitivan je efekat pentoksifilina na kontrakcije za vreme spontane ritmičke aktivnosti $i$ u prisustvu kalcijuma, $\mathrm{Ca}^{2+}$ (0.018 and 0.36 mM)) $i$ acetilholina (ACh).

Rezultati. Pentoksifilin je prouzrokovao koncentracijski zavisnu inhibciju spontane ritmičke aktivnosti, kao i fazne aktivnosti prouzrokovane kalcijumom. Inhibicijski efekt pentoksifilina zavisio je od tipa aktivacije glatkog mišića uterusa. On je ispoljio značajno jači relaksirajući efekt na spontanu ritmičku aktivnost $i$ kontrakcije prouzrokovane sa $0.018 \mathrm{mM}$ kalcijuma. Njegov relaksirajući efekt zavisi i od koncentracije $\mathrm{Ca}^{2+}$ u medijumu:Najslabiji relaksirajući efekat pentoksifilina je zabeležen na acetilholinskom tipu aktivacije. Nasuprot metilenskom plavilu, 4-aminopiridinu i tetraetilamonijumu, glibenklamid ne antagonizuje relaksirajući efekat pentoksifilina na izolovanom uterusu pacova.

Zaključak. Dobijeni rezultati sugerišu da u mehanizmu relaksantnog delovanja pentoksifilina nije zastupljeno otvaranje ATP kalijumskih kanala. Medutim, otvaranje BKCa $i$ voltažno zavisnih $\mathrm{Ca}^{2+}$ kalijumskih kanala ima izvestan značaj, ali u različitom stepenu, u mehanizmu relaksirajućeg delovanja pentoksifilina na spontanu ritmičku 
tractions of isolated rat uteri. Our results provide additional confirmation of the dominance of the NO/cGMP signalling pathway in the mechanism of the relaxing effect of pentoxifylline (because the presence of methylene blue significantly antagonised this effect) in relation to the opening of potassium channels, especially $K_{A T P}$ channels. These results indicate that pentoxifylline could be a potential tocolytic drug.

Keywords: pentoxifylline, rat uterus, potassium channel blockers, glibenclamide (GLB), tetraethylammonium (TEA), 4-aminopyridine (4- $A$ ), methylene blue $(M B)$

Running title: Potassium Channels in the Mechanism of Action of Pentoxifylline aktivnost $i$ kontrakcije prouzrokovane kalcijumom. Naši rezultati su dodana potvrda o dominaciji NO/cGMP signalinih puteva kojima pentoksifilin prouzrokuje relaksaciju glatkih mišičnih ćelija uterusa (jer metilensko plavilo značajno anntagonizuje njegov efekt), $u$ odnosu na otvaranje kalijumskih kanala, posebno ATP zavisnih kalijumskih kanala. Rezultati ukazuju da bi pentoksifiin mogao da bude potencijalni tokolitički lek.

Ključne reči: pentoksifilin, uterus pacova, blokatori kalijumskih kanala, glibenklamid (GLB), tetratilamonijum (TEA), 4-aminopiridin (4-AP) i metilensko plavilo

Kratki naslov: Kalijumski kanali u delovanju pentoksifilina

\section{INTRODUCTION}

Potassium channels are abundantly represented in the smooth muscle of the uterus ${ }^{1,2,3}$. Recent results show that the mechanisms of action of well-known powerful vasodilators such as sodium nitroprusside (NO donor), protamine sulphate and minoxidil involve the opening of potassium channelss of action. ${ }^{4,5,6,7}$

Pretreatment with tetraethylammonium (TEA, 6 $\mathrm{mmol} / \mathrm{l})$, an inhibitor of $\mathrm{BKCa}$ channels and a suppressor of two types of voltage-gated $\mathrm{K}^{+}$channel currents, decreased the protamine sulphate-mediated relaxation of both spontaneous and $\mathrm{Ca}^{2+}$-induced contractions. An inhibitor of voltage-gated K-channels, 4-aminopyridine (4-AP, $1 \mathrm{mmol} / \mathrm{l}$ ), and a selective ATP-sensitive potassium channel blocker, glibenclamide $(2 \mu \mathrm{mol} / \mathrm{l})$, decreased the protamine sulphate-mediated relaxation of $\mathrm{Ca}^{2+}$-induced contractions, without effects on the spontaneous contractions. Protamine sulphate acts downstream of cAMP- and cGMP-mediated phosphorylation at the level of BKCa and $\mathrm{Kv}$-channels in spontaneous contractions and at the level of all three K-channel types in $\mathrm{Ca}^{2+}$-induced contractions. ${ }^{7}$

Various types of tocolytics (most frequently beta ${ }_{2}^{-}$ adrenergic agonists) are used to prevent premature miscarriage and birth, but they have not yet solved these problems due to insufficient effectiveness and multiple side effects. ${ }^{8}$ For this reason, it is important to find new drugs with potential tocolytic characteristics, including calcium agonists, potassium channel openers and other vasodilators. ${ }^{9}$ It has been shown that even otomolar concentrations of nicardipine inhibit the spontaneous rhythmic activity of isolated uteri. ${ }^{10}$ Nitric oxide (NO), a mediator and modulator of numerous processes in the body under physiological and pathological conditions, plays a significant role in the mechanism of the relaxing effects of protamine sulphate and other vasodilators on smooth muscles. ${ }^{11}$ In cells, NO is created due to NO synthesis. ${ }^{12}$ High doses of Larginine increase blood flow through the blood vessels of the heart, mesentery, lungs and liver, without effecting the total peripheral resistance or blood pressure. ${ }^{13}$ L-arginine, however, can cause significant hypotension in normoten- sive rats, but only in animals pretreated with physostigmine. ${ }^{14}$ Experiments on animals have shown the presence of increased NO synthesis during normal pregnancy. In humans, a lack of NO causes vasoconstriction and preeclampsia. NO is characterised by extreme reactivity to intracellular enzymes. Additionally, $\mathrm{NO}$ affects the activity of guanylate cyclase (GC). The reaction between $\mathrm{NO}$ and GC can be inhibited with methylene blue. ${ }^{15}$

Pentoxifylline, a drug used to treat peripheral vascular disease, is a methyl xanthine derivative. Potential new indications for the application of this drug are under intensive study, as are its drug's mechanism of its action, which has not been sufficiently investigated on the molecular level. ${ }^{16}$

In our previous studies, we have shown that the endothelium plays a significant role in the pentoxifylline-induced relaxing of isolated rat mesenteric arteries. In the present experiment, we studied the effects of increasing pentoxifylline concentrations on various types of activation of isolated rat uteri (spontaneous rhythmic activity and contractions induced by calcium chloride at concentrations of $0.018 \mathrm{mM}$ and $0.36 \mathrm{mM}$ and by acetylcholine-ACh).

To elucidate the mechanism of action of pentoxifylline on the smooth muscles of the uterus, we studied the effects of this compound in the presence of: methylene blue, a guanylate cyclase blocker; tetraethylammonium (TEA, 6 $\mathrm{mM}$ ), a potassium channel antagonist, an inhibitor of $\mathrm{BKCa}$ channels and a suppressor of two types of voltage-gated $\mathrm{K}^{+}$ channel currents; 4-aminopyridine (4-AP, $1 \mathrm{mM}$ ), an inhibitor of voltage-gated K-channels; and glibenclamide (2 $\mu \mathrm{M})$, a selective ATP-sensitive potassium channel blocker.

\section{MATERIALS AND METHODS}

All protocols for handling rats were approved by the local Ethical Committee for Animal Experiments, which strictly follows international regulations. Isolated uteri of virgin Wistar rats (200-250 g) in oestrus, as determined by daily vaginal lavage, were used in this study. The uterus was 
suspended in an isolated organ bath chamber (Ugo Basile) containing De Jalon's solution ( $\mathrm{g} / \mathrm{l}: \mathrm{NaCl} 9.0, \mathrm{KCl} 0.42$, NaH$\mathrm{CO} 30.5, \mathrm{CaCl} 20.06$, glucose 0.5 ) and aerated with $95 \% \mathrm{O}_{2}$ and $5 \% \mathrm{CO}_{2}$. The temperature was maintained at $37^{\circ} \mathrm{C}$. Isometric contractions were recorded using an isometric force transducer (Ugo Basile). The uteri, either spontaneously active or treated with $\mathrm{Ca}^{2+}(6 \mathrm{mM})$, were allowed to equilibrate at $1 \mathrm{~g}$ tension before the experimental drugs were added. After stable spontaneous contractions had been established (approx. $20 \mathrm{~min}$ ), the uteri were treated with increasing concentrations of pentoxifylline $(0.05,0.11,0.22,0.54,1.08,2.16$, 3.23 and $4.31 \mathrm{mM}$ ) until total cessation of contractions. To explore the mechanism of action of pentoxifylline on the smooth muscle of the uterus, we studied the effects of this compound in the presence of tetraethylammonium (TEA, 6 $\mathrm{mM})$, 4-aminopyridine (4-AP, $1 \mathrm{mM})$, glibenclamide $(2 \mu \mathrm{M})$ and methylene blue $(0.9 \mu \mathrm{M})$. Each of the substances was added to De Jalon's solution 10 min before pentoxifylline.

The effects of the treatments on uterine contractions were calculated as the percentage of the control or untreated contractions. All data are expressed as the mean \pm SD. Differences between groups were evaluated by twoway ANOVA with treatment and dose as factors and were considered statistically significant when $\mathrm{p}<0.05$.
Pentoxifylline, methylene blue, tetraethylammonium (TEA), 4-aminopyridine (4-AP) and glibenclamide were purchased from Sigma-Aldrich (St. Louis, MO, USA). The salts for De Jalon's solution were obtained from ZORKA Pharma (Sabac, Serbia) and Merck (Darmstadt, Germany). All drugs were dissolved in distilled water, except for glibenclamide, which was dissolved in polyethylene glycol.

\section{RESULTS}

Influence of different types of uterine activation (spontaneous rhythmic activity and contractions induced by 0.018 and $0.36 \mathrm{mM} \mathrm{Ca}^{2+}$ and acetylcholine) on the relaxant effects of pentoxifylline

Increasing pentoxifylline concentrations $(0.05,0.11,0.22$, $0.54,1.08,2.16,3.23$ and $4.31 \mathrm{mM}$ ) caused the concentrationdependent inhibition of spontaneous rhythmic activity and contractions of isolated rat uteri induced by different concentrations of calcium chloride $\left(\mathrm{Ca}^{2+}, 0.018\right.$ and $\left.0.36 \mathrm{mM}\right)$ and by acetylcholine (ACh) (ANOVA, statistically significant effect of the concentration of pentoxifylline, $p<0.001$, Figure 1 ). However, the degree of relaxation depended on the type of activation (ANOVA, effect of type of activation, $p<0.001$ and

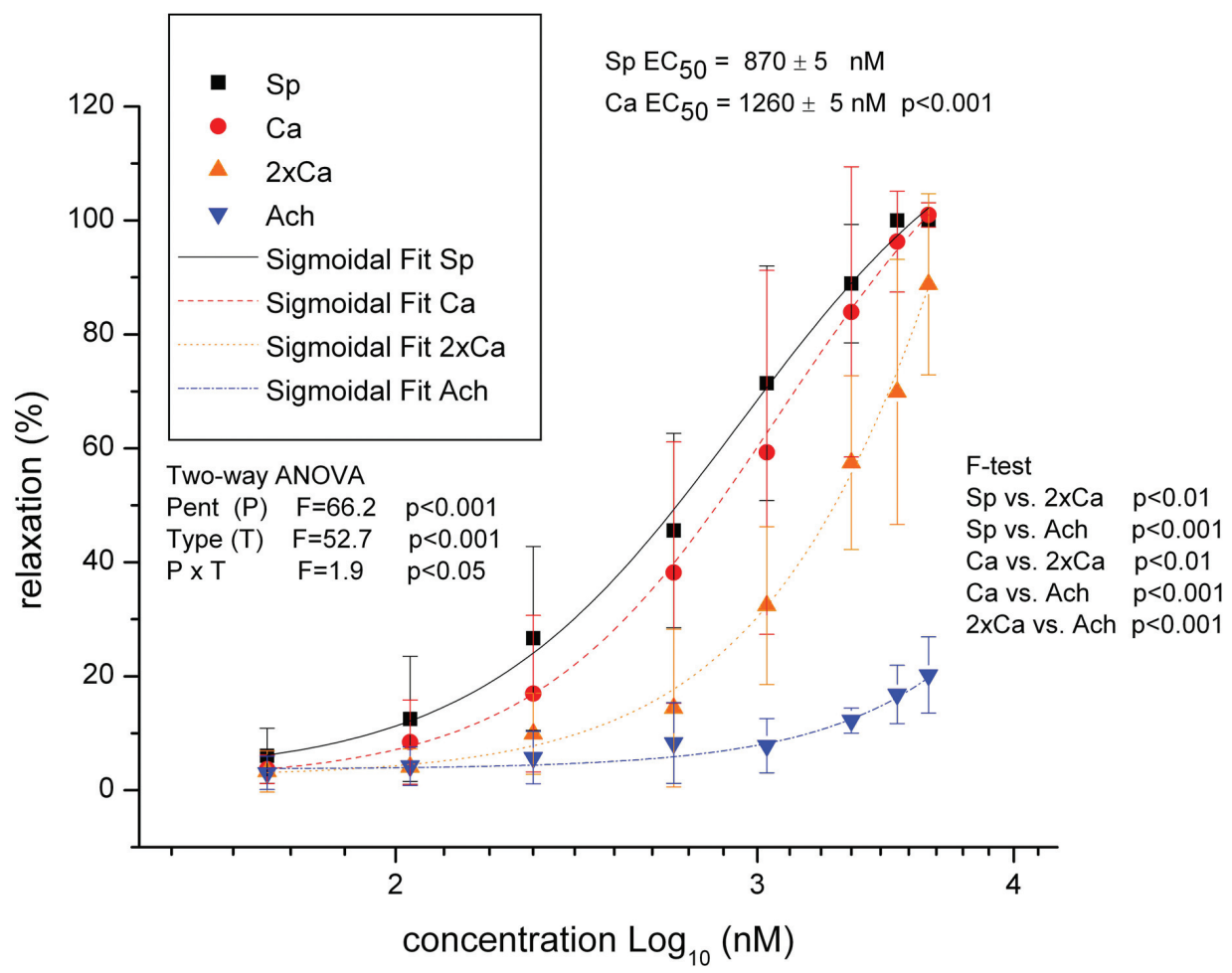

Fig. 1. Relaxation of spontaneous rhythmic activity and of $\mathrm{Ca}^{2+}-(0.018$ and $0.36 \mathrm{mM})$ and $\mathrm{ACh}$-induced activity of isolated rat uteri treated with pentoxifylline $(0.05,0.11,0.22,0.54,1.08,2.16,3.23$ and $4.31 \mathrm{mM})$. The black curve indicates the relaxant effect of pentoxifylline on spontaneous activity (Sp). The red curve indicates the relaxant effect of pentoxifylline on calcium $\left(\mathrm{Ca}^{2+}\right)$-induced activity $(0.018 \mathrm{mM})$. The red curve with triangles indicates the relaxant effect of pentoxifylline with a double concentration of calcium in the medium $(2 \times \mathrm{Ca}, 0.36 \mathrm{mM})$. The blue curve indicates the relaxant effect of pentoxifylline on acetylcholine-induced activity (ACh). The results are presented as the mean \pm standard deviation ( $\mathrm{n}=8-12$ experiments). The data were analysed using two-way ANOVA with concentration $(\mathrm{C})$ and activation type $(\mathrm{T})$ as factors ( $\mathrm{p}<0.05$ was considered significant). Pentoxifylline significantly relaxed spontaneous and Ca-activated rat uteri (ANOVA significant effect of concentration $(C), p<0.001$ ). The effect of pentoxifylline on ACh-induced uterine contractions was not significantly different from that on the other types of activation (significant ANOVA type effect (T), and C $\mathrm{x} T$ interactions). Sigmoidal fit curves were constructed and compared with the F-test. $\mathrm{EC}_{50}$ values were extracted from the curves and compared with the $\mathrm{t}$-test. The statistical significance of the differences is shown. The sigmoidal fit of the ACh-induced curve was not statistically significant $\left(\mathrm{Chi}^{2} / \mathrm{DoF}<0.05\right)$. 


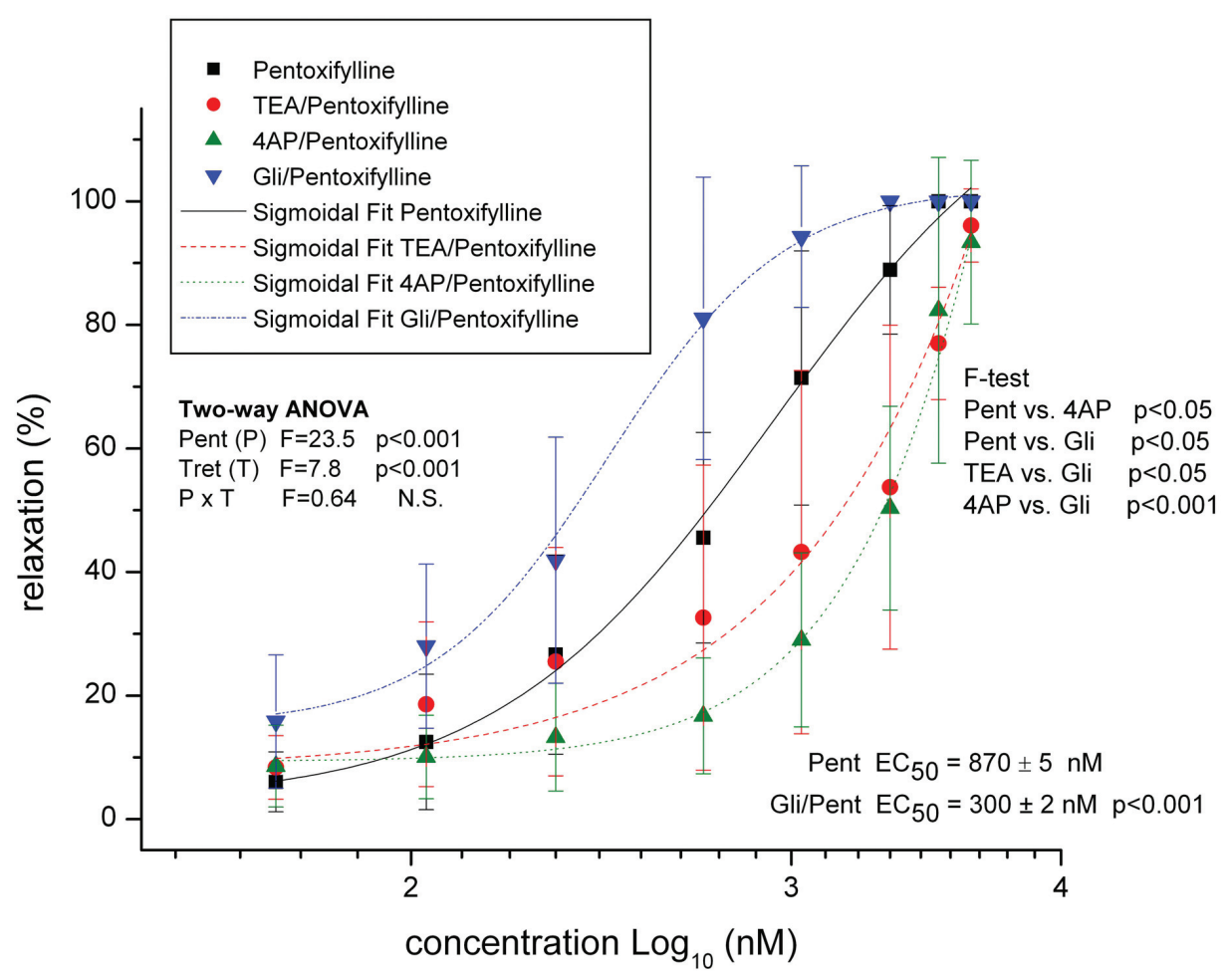

Fig. 2. Relaxation of spontaneous active rat uteri treated with pentoxifylline $(0.05,0.11,0.22,0.54,1.08,2.16,3.23$ and $4.31 \mathrm{mM})$ and pretreated with TEA, 4-AP or glibenclamide. The data are expressed as the mean $\pm \mathrm{SD}(\mathrm{n}=8-12)$. The red curve indicates the relaxant effect of pentoxifylline in the presence of tetraethylammonium (TEA/Pent), the blue curve indicates the relaxant effect of pentoxifylline in the presence of glibenclamide (GLB/ pentoxifylline), the green curve indicates the relaxant effect of pentoxifylline in the presence of 4-aminopyridine (4-AP/ pentoxifylline), and the black curve shows the relaxant effect of pentoxifylline on the spontaneous rhythmic activity of isolated rat uteri(control curve). The data were analysed using two-way ANOVA with concentration $(C)$ and pretreatment $(T)$ as factors ( $<<0.05$ was considered significant; NS - not significant). Sigmoidal fit curves were constructed and compared using the F-test. $\mathrm{EC}_{50}$ values were extracted from the curves and compared with the t-test. The statistical significance of the differences is shown. The sigmoidal fit of the curve for TEA-pretreated uteri was not statistically significant $\left(\mathrm{Chi}{ }^{2} / \mathrm{df}=0.24\right)$.

interaction P x T p<0.05). Pentoxifylline exhibited stronger relaxing effects on the spontaneous rhythmic activity and the contraction of the uterus induced by $0.018 \mathrm{mM} \mathrm{Ca}^{2+}$ (lowest $\left.\mathrm{EC}_{50}\right)$. Pentoxifylline exerted the weakest relaxant effects on the contractions induced by acetylcholine.

The relaxing effect of pentoxifylline was lower for the $\mathrm{Ca}^{2+}$-stimulated and activity compared to the spontaneous rhythmic activity, which is reflected by the significantly higher $\mathrm{EC}_{50}$ for this type of active uterus. The relaxation curves for the spontaneously contracting and $\mathrm{Ca}^{2+}$-activated uteri were statistically modelled using the sigmoid model $\left(\mathrm{Chi}^{2} / \mathrm{DoF}<0.05\right)$, whereas in the activated uteri, the calcium double $\left(0.36 \mathrm{mM} \mathrm{Ca}{ }^{2+}\right)$ sigmoid model was not significant due to the lack of a dose that would cause the maximum relaxation effect.

For uterine contractions induced by acetylcholine (ACh), the pentoxifylline concentrations used were too low to cause significant concentration-dependent relaxation, and thus, the effects could not be modelled in a sigmoid manner. A comparison of the F-test curves showed that the curves for active and spontaneous $\mathrm{Ca}^{2+}$-stimulated active uteri have similar slopes and are significantly different compared to the other two types.

Influence of the potassium channel blockers glibenclamide (GLB), 4-aminopyridine (4-AP) and tetraethylam- monium (TEA) on the relaxant effect of pentoxifylline on the spontaneous rhythmic activity of isolated rat uteri.

To elucidate the mechanism of pentoxifylline's relaxant effect on the smooth muscles of the uterus and the possible role of potassium channels, that which are abundantly present in the smooth muscle of the uterus, we studied the effects of this compound in the presence of potassium channel blockers including TEA (an inhibitor of BKCa channels and a suppressor of two types of voltage-gated $\mathrm{K}^{+}$channel currents), 4-AP (an inhibitor of voltage-gated K-channels) and GLB (a selective ATP-sensitive potassium channel blocker) on the spontaneous rhythmic activity of isolated rat uteri. In a second series of experiments, we completed the same studies infor calcium-induced contractions.

When a uterus with spontaneous rhythmic activity was pretreated with TEA, 4-AP or glibenclamide, the activity level depended on the concentration of the reserves of the relaxant pentoxifylline (ANOVA, statistically significant effect of the concentration of pentoxifylline, $p<0.001$, Figure 2), but this does not significantly change the degree of relaxation, depending on the pretreatment (ANOVA, statistically significant effect of pretreatment $\mathrm{p}<0.001$; the differences are reflected in the $\mathrm{EC}_{50}$ values and the effects of the sigmoid comparisons of the modelled fault). Pretreatment with glibenclamide resulted in a statistically 


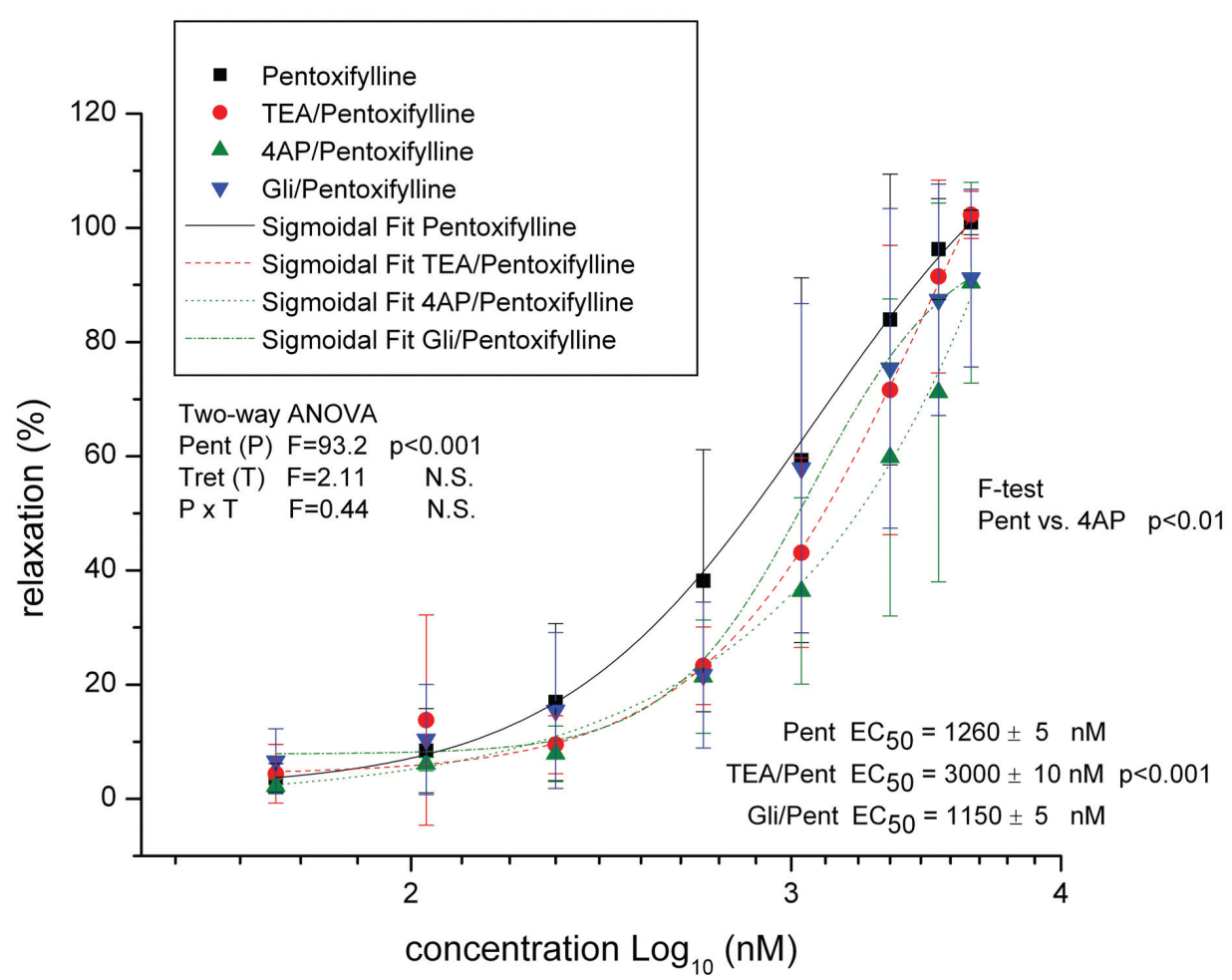

Fig. 3. Relaxation of $\mathrm{Ca}^{2+}$-activated rat uteri treated with pentoxifylline $(0.05,0.11,0.22,0.54,1.08,2.16,3.23$ and 4.31 mM) and pretreated with TEA, 4-AP or glibenclamide. The data are expressed as the mean \pm SD $(n=8-12)$. The red curve indicates the relaxant effect of pentoxifylline in the presence of tetraethylammonium (TEA/ pentoxifylline), the blue curve indicates the relaxant effect of pentoxifylline in the presence of glibenclamide (GLB/ pentoxifylline), the green curve indicates the relaxant effect of pentoxifylline in the presence of 4-aminopyridine (4-AP/ pentoxifylline), and the black curve represents the relaxant effect of pentoxifylline on the calcium-induced activity of isolated rat uteri (control curve). The data were analysed by two-way ANOVA with concentration $(C)$ and pretreatment $(T)$ as factors ( $<<0.05$ was considered significant; NS - not significant). Sigmoidal fit curves were constructed and compared with the F-test. $\mathrm{EC}_{50}$ values were extracted from the curves and compared with the $\mathrm{t}$-test. The statistical significance of the differences is shown. The sigmoidal fits of the curves for the uteri pre-treated with 4-AP and glibenclamide were not statistically significant (Chi ${ }^{2} /$ $\mathrm{df}=0.2$ and 0.09 , respectively).

significant increase in the relaxing effect of pentoxifylline (significantly lower $\mathrm{EC}_{50}$ and a different slope expressed by the F-test, Figure 2), whereas pretreatment with 4-AP significantly decreased the relaxation effect, especially in the lower concentration range (statistically expressed by the Ftest; 4-AP pretreatment did not change the relaxant effect of the highest dose of pentoxifylline).

In this series of experiments, we showed that the presence of glibenclamide $(2 \mathrm{mM})$ stimulated the relaxant effect of increasing concentrations of pentoxifylline on the spontaneous rhythmic activity of isolated rat uteri. In control experiments without glibenclamide, pentoxifylline caused significant inhibition of the spontaneous rhythmic activity at a concentration of $19.2 \mathrm{mM}$. However, in most experiments, a pentoxifylline concentration of $6.6 \mathrm{mM}$ was sufficient for the total inhibition of spontaneous rhythmic contractions in the presence of glibenclamide (Figure 2).

Influence of potassium channel blockers (glibenclamide, 4-aminopyridine and tetraethylammonium) on the relaxant effect of pentoxifylline on the contractions of isolated uteri induced by calcium

According to the analysis of variance, pretreatment of a $\mathrm{Ca}^{2+}$-induced active uterus with TEA, 4-AP or glibenclamide did not affect the degree of relaxation induced by pentoxifylline (ANOVA, no statistically significant effect of pretreatment; Figure 3). However, a comparison of the $\mathrm{EC}_{50}$ values and the comparison of the F-test curves areindicate that pretreatment with TEA reduced the relaxant effect of pentoxifylline (statistically significant difference in the $\mathrm{EC}_{50}$ values relative to pentoxifylline alone), mainly due to its efficacy at lower concentrations. Pretreatment with 4-AP decreased the relaxing effect of higher concentrations of pentoxifylline, and thus, the pentoxifylline applied after pretreatment with 4-AP could achieve the maximum relaxation effect, which led to statistically significant differences in the slope of the sigmoid curves (Ftest, $\mathrm{p}<0.05)$.

Influence of pentoxifylline on the spontaneous rhythmic activity of isolated rat uteri in the presence of methylene blue

In these experiments, the effects of increasing concentrations of pentoxifylline on the spontaneous rhythmic activity of isolated rat uteri were studied in the presence of methylene blue $(0.9 \mathrm{mM})$. Methylene blue (a guanylate cyclase blocker) statistically significantly $(\mathrm{p}<0.001)$ antagonised the relaxing effect of pentoxifylline on the spontaneous rhythmic activity of isolated rat uteri. For example, in the presence of methylene blue, even the highest concentration of pentoxifylline did not cause complete inhibition of uterine contractions (Figure 4.). 


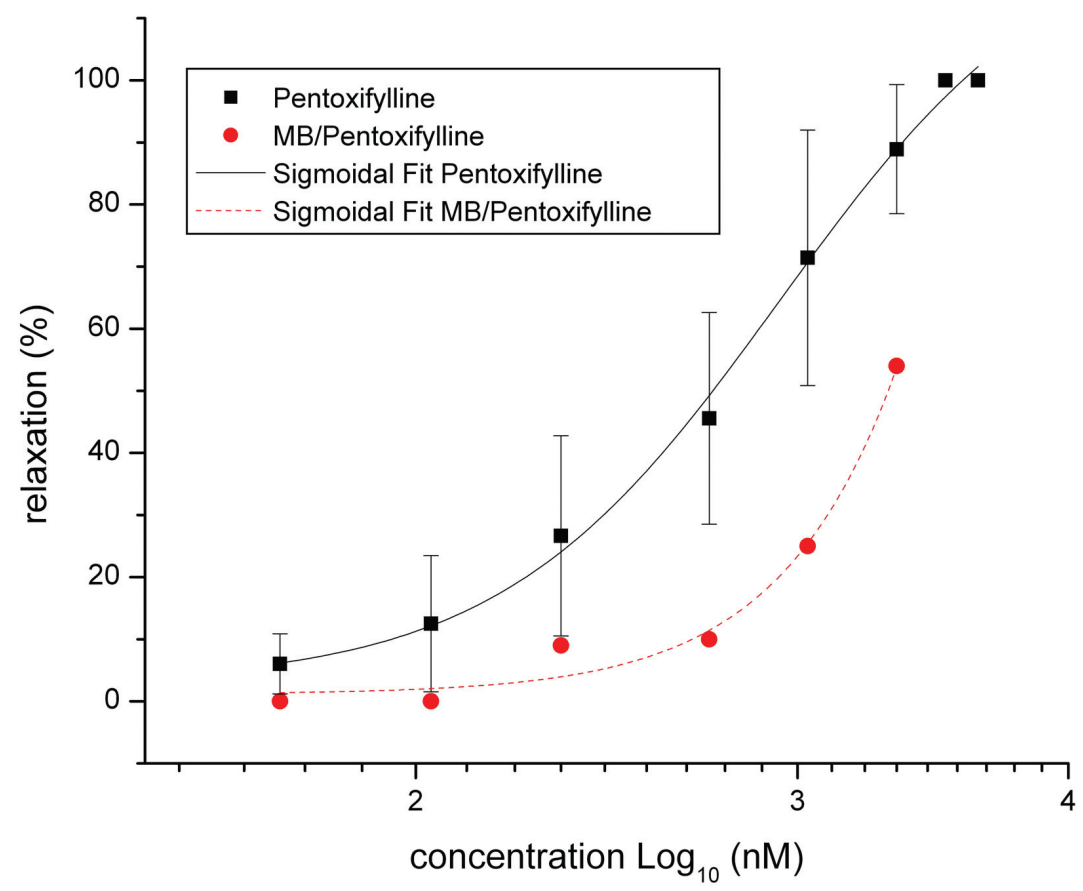

Fig. 4. The relaxing effect of increasing concentrations of pentoxifylline $(0.05,0.11,0.22,0.54,1.08,2.16,3.23$ and $4.31 \mathrm{mM})$ on the spontaneous rhythmic activity of isolated rat uteri and on the spontaneous activity of isolated rat uteri pretreated with methylene blue (MB). The red curve indicates the relaxant effect of pentoxifylline in the presence of $\mathrm{MB} /$ pentoxifylline. The blue curve is the control experiment with pentoxifylline without MB. The results are presented as the mean $\pm \mathrm{SD}(\mathrm{n}=8-12$ experiments). The statistical significance of the effects was tested by two-factor ANOVA, with the concentration of pentoxifylline $(\mathrm{P})$ and the type of pretreatment $(\mathrm{T})$ as factors. Curves were modelled using the sigmoid model and compared by the F-test. The F-test comparison showed a statistically significant difference between the modelled sigmoid curves. Pretreatment with methylene blue significantly antagonised the relaxant effect of increasing concentrations of pentoxifylline $(\mathrm{p}<0.001)$.

\section{DISCUSSION}

Pentoxifylline induced the concentration-dependent inhibition of spontaneous rhythmic activity and contractions in isolated rat uteri induced by calcium $(0.018 \mathrm{mM}$ and 0.16 $\mathrm{mM}$ ) and acetylcholine (ACh). We showed that the degree of the inhibitory effect of pentoxifylline depends on the type of muscle activation and the effect of this compound is significantly stronger on spontaneous rhythmic activity (lowest $\mathrm{EC}_{50}$ ) and contractions caused by $0.018 \mathrm{mM}$ calcium. In contrast, this effect is very weak when the uterus is stimulated by ACh. The activation of isolated uteri with double the amount of calcium reduced the relaxant effect of pentoxifylline so that even at the highest concentrations, there was no complete relaxation. Compared to the results obtained from the spontaneous rhythmic activity, the relaxant effect of pentoxifylline was weaker for calcium-induced contractions of the isolated uteri. These results show that pentoxifylline may be a potential drug that could be used to prevent premature births and miscarriages.

Our results show that the degree of pentoxifylline's inhibitory effect depends on the muscle activation type are in accordance with the data in the literature regarding calcium antagonist's effects on the contraction of the smooth muscle of the uterus. However, differences in the inhibitory effects of vasodilatory substances are most pronounced in experiments with calcium antagonists. For instance, nicardipine and nitrendipine have the most potent inhibitory effects on the contractions of isolated rat uteri caused by electrical stimulation (inhibited by otomolar concentrations), with weaker effects on spontaneous rhythmic activity and acetylcholine-induced activity. The weakest effect is on oxytocin-induced activities (inhibited by micromolar concentrations). ${ }^{10,31}$

Our experiments and those of other authors also showed that pentoxifylline has a weaker relaxing effect on muscle activity in the presence of added extracellular calcium than on spontaneous rhythmic activity. This result suggests that spontaneous rhythmic muscle activity could depend on the calcium concentration present in the cell to a greater extent than previously expected. ${ }^{5}$ Protamine sulphate also caused concentration-dependent relaxation infor both types of contractions. ${ }^{6}$

Spontaneous rhythmic muscle activity is achieved by calcium influx into the cells from extracellular spaces through calcium channels located in the cellular membrane. This signifies that spontaneous rhythmic activity depends primarily on the calcium concentrations present outside the cell. Other types of muscle activation (caused by acetylcholine or oxytocin) depend more on intracellular calcium or calcium that enters the cell via the activation of muscarinic and oxytocin receptors. ${ }^{17,18}$

Potassium channels are present in numerous types of

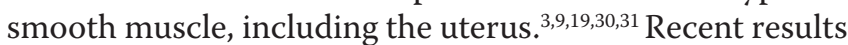
show that the mechanisms of action of some known potent 
vasodilators, such as sodium nitroprusside (NO donor) and minoxidil, involve the opening of potassium channelss of action. ${ }^{3,4,7,20}$

One of the most studied types, which is dominant in the smooth muscles of the uterus, is the large calcium dependent potassium channel, $\mathrm{BK}_{\mathrm{ca}}$ or maxi K. During gestation, its importance is even greater, especially during delivery because its inhibition provides an increased level of intracellular $\mathrm{Ca}^{2+}$, which is necessary for birth contractions. ${ }^{21}$ Additionally, there is the important role of ATP-dependent potassium channels $\left(\mathrm{K}_{\mathrm{ATP}}\right)$ in the smooth muscles of the uterus. They form the connection between the metabolic state of the cell and cell excitation, i.e., contractility. .1,22,27,28,29,31 $^{2}$

Changes in the expression and activity of potassium channels are very important for the control of uterine contractility. ${ }^{9}$ For example, $\mathrm{H}_{2} \mathrm{O}_{2}$ induces concentrationdependent relaxation of isolated rat uteri via potassium "voltage-dependent channels". ${ }^{3,31}$ Based on these findings, studying the influence of potassium channel modulators and their interactions with $\mathrm{NO}$ on uterine tissue is important for both uterine physiology and pathophysiology studies and for finding new therapeutic concepts in the treatment of uterine contractility disturbances. ${ }^{6,9,10}$

$\mathrm{H}_{2} \mathrm{O}_{2}$ oxidises intracellular thiol groups in the potassium voltage-related channel and activates the channel, inducing relaxation. The cell's antioxidative defence system quickly activates the glutathione peroxidase (GSHPx) defence mechanism, but not the catalase (CAT) defence mechanism. Intracellular redox mechanisms repair the oxidised sites and again establish the deactivated state of $K V$ channels, recuperating contractility. In conclusion, this activity demonstrates that $K V$ channels can be altered in a time-dependent manner by reversible redox-dependent intracellular alterations. ${ }^{31}$

Together with detailed information about $\mathrm{K}^{+}$channels, there is a pronounced pharmaceutical interest in the synthesis and development of selective $\mathrm{K}^{+}$channel modulators. Scientists are also reevaluating the spectrum of existing drugs and substances that influence the permeability of smooth muscle cell membranes for $\mathrm{K}^{+}$ions, especially those vasodilators with-direct effects: minoxidil, diazoxide, and dimethyl sulfoxide (DMSO), which is a widely used solvent. ${ }^{2,5,6,10,30}$

Because there is insufficient data demonstrating whether, in addition to the $\mathrm{NO} / \mathrm{cGMP}^{5}$ system, potassium channels (channel type and role) also participate in the mechanism of the relaxant effect of pentoxifylline, we investigated the effect of this compound in the presence of various potassium channel blockers: glibenclamide ( $\mathrm{K}_{\text {ATP }}$ channel blocker), 4-aminopyridine $\left(\mathrm{BK}_{\mathrm{Ca}}\right.$ blocker) and tetraethylammonium (voltage dependent $\mathrm{Ca}^{2+}$ channel blocker).

In these experiments, we showed that the opening of potassium channels does not play as important a role in the mechanism of action of pentoxifylline as in the case of pinacidil or protamine sulphate. Generally, in both types of activation, the opening of $\mathrm{K}_{\mathrm{ATP}}$ channels is not important for the relaxant effect of pentoxifylline.
In our experiments, we found that the relaxing effect of pentoxifylline was higher in the presence of glibenclamide, a selective blocker of $K_{A T P}$ channels. The complete inhibition of contractions in the presence of glibenclamide was achieved by lower pentoxifylline concentrations.

Pretreatment with glibenclamide, a $\mathrm{K}_{\text {ATP }}$ channel blocker, even led to a statistically significant increase in the relaxing effect of pentoxifylline. Glibenclamide, an antagonist of this type of potassium channel, led to prolonged depolarisation and prevented the output current of potassium that is responsible for the repolarisation of the cell membrane.

However, it has been shown that glibenclamide leads to the inhibition of contractions of arterial muscle elements, most likely by interacting with and blocking voltage-dependent calcium channels. ${ }^{24,25}$ Our results could be interpreted in the same way. It is possible that glibenclamide stimulates the relaxing effect of pentoxifylline by blocking voltage-dependent calcium channels, thus decreasing the flux of calcium into the cell and causing relaxation of the muscles. ${ }^{5}$

However, pretreatment with 4- $\mathrm{AP}\left(\mathrm{BK}_{\mathrm{Ca}}\right.$ blocker) significantly reduced the relaxant effect of pentoxifylline on spontaneous rhythmic activity but did not change the relaxant effect of the highest concentrations of pentoxifylline. For calcium-induced activation, TEA (a voltage-dependent $\mathrm{Ca}^{2+}$ channel blocker) reduced the relaxant effect of pentoxifylline, mostly because of its efficiency at lower concentrations. This result is dissimilar to the pretreatment with 4-AP, which decreased the relaxant effect of higher concentrations of pentoxifylline; in the presence of 4-AP, pentoxifylline could not reach its maximum relaxant effect (F-test, $\mathrm{p}<0.05)$. These findings indicate that the mechanism of action of pentoxifylline is not related to the opening of $\mathrm{K}_{\mathrm{ATP}}$ channels, as is the case for other vasodilators, such as minoxidil and pinacidil. However, the opening of $\mathrm{BK}_{\mathrm{Ca}}$ and voltage-dependent $\mathrm{Ca}^{2+}$ channels has some role, but to varying degrees, in the mechanism of the relaxing effect of pentoxifylline on spontaneous rhythmic activity and contractions of isolated rat uteri induced by calcium.

Our results are an additional confirmation of the dominance of NO/cGMP in the mechanism of the relaxing effect of pentoxifylline in relation to the opening of potassium channels, especially $\mathrm{K}_{\text {ATP }}$ channels. Given that the relaxant effect of pentoxifylline depends on the calcium concentration (it is weaker if the contractile activity is induced with $0.16 \mathrm{mM}$ than with $0.018 \mathrm{mM}$ ), we can say that pentoxifylline, to some extent, acts as a calcium antagonist. Our results also suggest that pentoxifylline may be a potential tocolytic agent. However, to reach a definitive conclusion, it is necessary to test the relaxing effect of pentoxifylline on the uterus in vivo in order to monitor for possible side effects.

In this series of experiments, we found that all three $\mathrm{K}^{+}$ channel blockers used in the experiments antagonised the inhibitory effect of pentoxifylline on spontaneous rhythmic activity and phase activity caused by calcium to some extent. However, unlike our results obtained with protamine and pinacidil, glibenclamide exerted a poor (statistically 
insignificant) antagonistic effect at a concentration of 3 $\mu \mathrm{M}$, while for 4-AP and TEA, only concentrations of $3 \mathrm{mM}$ proved more effective. However, only 4-AP had a somewhat significant effect on pentoxifylline inhibition.

Our results show that the opening of potassium channels (especially of the $K_{\text {ATP }}$ type) does not have any significant role in the relaxant mechanism of pentoxifylline, except to a certain extent for BKCa calcium channels. In contrast to these results with pentoxifylline, our results and the results of other authors with the relaxant pinacidil (a calcium channel opener) show that calcium channel opening, especially that of the $\mathrm{K}_{\text {ATP }}$ type, plays a significant role in this compound's mechanism of action ${ }^{3,5,6,9}$. The role of potassium channel opening in the relaxant effect of vasodilators seems to depend on the type of tissue. ${ }^{24}$ Likely, potassium channel opening is more important for the relaxant effect of certain vasodilatory substances in the case of blood vessels than in the case of the uterus.

Methylene blue inhibits the production of cGMP by preventing the interaction of NO with guanylate cyclase. The results of our earlier series of experiments ${ }^{5}$ and the present experiments $(n o=12)$ with new statistical analyses of these results also showed that methylene blue decreased the relaxing effect of pentoxifylline on the spontaneous rhythmic activity of isolated rat uteri. Not even the highest applied concentration of pentoxifylline achieved complete discontinuation of contractions.

The data indicating that methylene blue antagonises the relaxing effect of Na-nitroprusside ${ }^{12}$ and pentoxifylline ${ }^{5}$ are in accordance with both our earlier ${ }^{5}$ and present results. Methylene blue makes the activation of guanylate cyclases impossible and thus prevents muscle relaxation. cGMP activates cGMP-dependent protein kinase, which blocks the entrance of calcium ions, activates potassium channels and decreases the IP3 level, finally leading to vasodilatation. However, it has been shown that methylene blue cannot antagonise the relaxing effects of sodium azide and nitroglycerol. ${ }^{25}$ Additionally, pretreatment with methylene blue $(0.3 \mu \mathrm{g} / \mathrm{ml})$ had no effect on protamine-induced ation, despite the use of $\mathrm{N}(\mathrm{G})$-nitro-L-arginine methyl ester (L-NAME, $10^{-5} \mathrm{M}$ ) and propranolol $(5 \mu \mathrm{g} / \mathrm{ml})$, which potentiated the protamine's relaxing effect on the spontaneous contractile activity of isolated rat uteri and had no effect on $\mathrm{Ca}^{2+}$-induced contractions. ${ }^{2}$ L-arginine in the cell is used as the substance for the synthesis of $\mathrm{NO}$ and can raise NO concentrations, leading to smooth muscle cell relaxation. In human and animal models not able to produce NO due to endothelial dysfunction, it has been shown that L-arginine restores the lost ability of endothelium-dependent vasodilatation.

Unlike methylene blue (a guanylate cyclase blocker), Larginine (an NO precursor) does not antagonise the relaxation effect of pentoxifylline on the contraction of isolated rat uteri, except partially in spontaneous rhythmic activity (without changing its maximum inhibitory effect). ${ }^{5}$ These results suggest that pentoxifylline most likely achieves its relaxing effect on the uterus regardless of the presence of nitric oxide.
In contrast to our results, in experiments on isolated renal and mesenteric arteries taken from normotensive and hypertensive rats, it has been found that L-arginine even antagonised the relaxation caused by sodium nitroprusside. ${ }^{18}$ The authors found a possible explanation for the noted phenomenon in the ability of sodium nitroprusside to achieve its action through peroxynitrate and not through S-nitrosothiol.

The results of our earlier series of experiments with L-arginine $(0.3 \mu \mathrm{mol})$ and pentoxifylline $\mathrm{e}^{5}$ and the results of our present experiments with methylene blue suggest that NO is not significantly involved in pentoxifylline's effects. There are data regarding the existence of signalling pathways in the cell, including NO-independent cGMP creation, that do not lead to relaxation. ${ }^{5}$

In many papers, pentoxifylline is referred to as a phosphodiesterase blocker. ${ }^{26}$ By blocking phosphodiesterase, pentoxifylline directly increases the cAMP levels in muscle cells, leading to relaxation. Because methylene blue (a guanylate cyclase blocker) decreased the inhibitory effects of pentoxifylline, it is possible that even cGMP is involved in muscle relaxation via signalling pathways not dependent on NO.

\section{CONCLUSIONS}

Pentoxifylline, which is used to treat peripheral vascular disease, is a derivative of methylxanthines. One of the mechanisms of action of pentoxifylline is through the vasodilatation of blood vessels. This study examined the effect of increasing concentrations of pentoxifylline on the contractility of isolated rat uterus in the presence of a potassium channel antagonist and methylene blue. Uteri were allowed to contract spontaneously or in the presence of $\mathrm{Ca}^{2+}(0.018$ and $0.36 \mathrm{mM})$ and acetylcholine and were then treated with pentoxifylline.

Our results suggest that the mechanism of action of pentoxifylline does not include the opening of $\mathrm{K}_{\text {АTP }}$ channels. However, the opening of $\mathrm{BKCa}$ and voltage dependent $\mathrm{Ca}^{2+}$ channels has some role, but to varying degrees, in the mechanism of the relaxing effect of pentoxifylline on spontaneous rhythmic activity and the contraction of isolated rat uteri induced by calcium. Pretreatment with glibenclamide, a $\mathrm{K}_{\mathrm{ATP}}$ channel blocker, led to a statistically significant increase in the relaxing effect of pentoxifylline. Glibenclamide, an antagonist of this type of potassium channel, led to prolonged depolarisation, preventing the output current of potassium that is responsible for the repolarisation of the cell membrane.

The degree of the inhibitory effect of pentoxifylline depended on the type of muscle activation; it was significantly stronger against spontaneous rhythmic activity (lowest $\mathrm{EC}_{50}$ ) and contractions caused by a $0.018 \mathrm{mM}$ calcium and was very weak when the uterus was stimulated by ACh. The activation of isolated uteri with double the amount of calcium reduced the relaxant effect of pentoxifylline so that even at the highest concentrations used there was no complete relaxation. 
Compared to the effect on spontaneous rhythmic activity, the relaxing effect of pentoxifylline was lower for the contraction of isolated rat uteri induced by $\mathrm{Ca}^{2+}$.

Our results provide additional confirmation of the dominance of the NO/cGMP signalling pathway in the mechanism of the relaxing effect of pentoxifylline (because the presence of methylene blue significantly antagonised this effect) in relation to the opening of potassium channels, especially $\mathrm{K}_{\mathrm{ATP}}$ channels. These results indicate that pentoxifylline could be a potential tocolytic drug.

\section{REFERENCES}

1.Oreščanin-Dušić $Z$, Milovanović $S$, Blagojevic $D$, Nikolic-Kokić A, Radojičić R, Spasojević I, Spasić BM: Diethyldithiocarbamate potentiates the effects of protamine sulfate in the isolated rat uterus. Redox Report, 2009a, 14, 48-54.

2.Oreščanin-Dušić $Z$, Milovanović $S$, Radojičić $R$, Nikolić-Kokić A, Appiah I, Slavić M, Čutura N, Trbojević S., Spasić M, Blagojević D. Effects of protamine sulfate on spontaneous and $\mathrm{Ca}$-induced contractile activity in the rat uterus are potassium channels mediated. Gen. Physiol. Biophys, 2009b, Special Issue, 28, 143-148.

3. Jokanović D, Stanković, Kordić-Bojinović J, OreščaninDušić Z, Nikolić-Kokić A, Slavić M, Mihajlo Spasić, Duško Blagojević and Milovanović RS. The effect of pinacidil on the various type activation of the isolated rat uterus. 16th World Congress of Basic and Clinical Pharmacology (World Pharma 2010), Copenhagen, Denmark, 17 - 23 July 2010.

4. Schubert U, Krien U, Wulfusen I. Nitric oxide donor sodium nitropruside dilates rat small arteries by activation of inward rectifier potassium channels. Hypertension 2004; 43:891-96.

5. Kordić-Bojinović J, Jokanović D, Stanković D, Janković $\mathrm{S}$, Milovanović S. Influence of modulators of relaxant effect of pentoxifylline in isolated rat uterus, Ser J Exp Clin Res 2010; 11 (3): 99-104.

6. Kordić-Bojinović J, Oreščanin-Dušić $Z$, Slavić $M$, Radojičić R, Spasić M, Milovanović SR, Blagojević D. Effect of indometacin pretreatment on protamine sulfate-mediated relaxation of the isolated rat uterus: the role of the antioxidative defense system. Pharmacol Rep. 2011;63(4):1019-28.

7.Sokolović D, Drakul D, Oreščanin-Dušić Z, NikolićKokić A, Spasić M, Blagojević D and Milovanović RS. The role of potassium channels in the mechanism of relaxing effect of minoxidil on the isolated rat uterus. 6 th European Congress of Pharmacology held in Granada, July 17th - 20th, 2012.

8. Kalezić I, Rodić V, Kitanović S, Milovanović G, Zgradić I and Milovanović S. The Effects of Ritodrine, on a receptors in smooth uterine muscle and heart atria of rats. Arch Toxicol Kinet Xenobiot Metab 1993; 1:112-118.
9. Novaković R, Milovanović SR, Heinle H, Protić D, and Gojković-Bukarica Lj. The effect of potassium channel opener pinacidil on non-pregnant rat uterus. Basic \& Clinical Pharmacology \& Toxicology 2007;1742-84.

10. Milovanovic S R, Ognjanović J, Varagic VM, Bosković B. Effect of nicardipine of the isolated rat uterus and other smooth muscles of the rat. Archives Internationales de Pharmacodynamic et de Therapie 1988; 295: 1348-58.

11. Oreščanin-Dušić Z, Milovanović $S$, Spasić M, Radojičić $\mathrm{R}$, Blagojević D. Effect of protamine sulfate on the isolated mesenteric arteries of normotensive and spontaneously hypertensive rats. Arch Biol Sci 2008;60:163-168.

12. Orescanin Z, Milovanović SR, Spasic DS, Jones DR, Spasić MB. Different responses of mesenteric artery from normotensive and spontaneousely hypertensive rats to nitric oxide and its redox congeners. Polish Pharmacological Reports 2007; 59: 322-329.

13. Van Geldern EM, Heilingers JPC, Saxena PR. Hemodynamic changes and acetylholine-induced hypotensive responses after $\mathrm{N}$-nitro-L-arginine-methyl-ester in rats and cats. Br J Pharmacol 1991;103:1899-1904.

14. Prostran M, Varagic VM, Todorovic Z, Jezdimirovic M. The effects of physostigmine, L-arginine and N-nitroL-arginine-methyl-ester (L-NAME) on the mean arterial blood pressure of the rat. J Basic Clin Physiol Pharmacol 1994; 5:151-166.

15. Choi JW, Im MW, Pai SH. Nitric oxide production increases during normal pregnancy and decreases in preeclampsia. Ann Clin Lab Sci 2002; 3:257-63.

16. Matson, PL, Yovich, JM, Edirisinghe, WR et al. An argument for the past and continued use of pentoxifylline in assisted reproductive technology. Hum Reprod 1995 (Suppl): 10; 67-71.

17. Varagić, VM, Milovanović SR, Srkalović, G. The effect of calcium-channel-blocking agents on the various types of smooth muscle activation of the isolated rat uterus. Arch Int Pharmacodyn 1984; 270; 79-87.

18. Oreščanin Z, Milovanović S. Effect of L-arginine on the relaxation caused by sodium nitroprusside on isolated rat renal artery. Acta Physiologica Hungarica 2006; 93:271-283.

19. Gojković-Bukarica L, Kazić T. Differential effects of pinacidil and levcromakalim on the contractions elicited electrically or by noradrenaline in the portal vein of the rabbit. Fundam Clin Pharmacol 1999;3:527-34.

20. Schubert U, Krien U, Wulfusen I. Nitric oxide donor sodium nitropruside dilates rat small arteries by activation of inward rectifier potassium channels. Hypertension 2004; 43:891-96.

21. Khan R N, Matharoo-Ball B, Arulkumaran S, Ashford M LJ. Potassum channels in the human myometrium. Experimental Physiology 2001; 862: 255-64.

22. Morrison JJ, Ashford MLJ, Khan RN, Smith S K. The effects of potassium channel openers on isolated pregnant human myometrium before and after the onset of labor: potential for tocolysis. Ат J Obstet Gynecol 1993;169:1277-85. 
23. Appiah I, Milovanović S, Radojicic R, Nikolic-Kokić A, Orescanin-Dusić Z, Slavić M, Trbojević S, Skrbić R, Spasić MB and Blagojević D. Hydrogen peroxide affects contractile activity and anti-oxidant enzymes in rat uterus. British Journal of Pharmacology 2009;158:1932-41.

24. Crosbie AE, Vuylsteke A, Ritchie AJ, Latimer RD, Callingham BA.: Inhibitory effects of glibenclamide on the contraction of human arterial conduits used in coronary artery bypass surgery. J Pharm Pharmacol 2000;52:333-40.

25. Milovanović SR, Varagić VM, Kovacević V. The effect of nitro compounds on the metabolism of cGMP and the activity of the isolated rat uterus. Iugoslav Physiol Pharmacol. Acta 1985(Suppl. 3); 21:12-16.

26. Calogero, AE, Fishel, S, Hall, J. Correlation between intracellular cAMP content, kinematic parameters and hyperactivation of human spermatozoa after incubation with pentoxifylline. Hum Reprod 1998;13: 911-15.

27. Khan RN, MorrisonJJ, Smith SK, Ashford ML.Activation of large-conductance potassium channels in pregnant human myometrium by pinacidil. Am J Obstet Gynecol. 1998 May;178(5):1027-34.
28. Khan RN, Smith SK, Morrison JJ, Ashford ML. Properties of large- conductance $\mathrm{K}+$ channels in human myometrium during pregnancy and labour. Proc Biol Sci. 1993 Jan 22;251(1330):9-15.

29. Khan, Kovacic, Kolbanovskiy, Desai, Frenkel \& Geacintov (2000) The decomposition of peroxynitrite to nitroxyl anion (NO-) and singlet oxygen in aqueous solution. Proc Natl Acad Sci U S A 97, 2984-2989.

30. Slavic M, Djordjevic A, Radojicic R, Milovanovic S, Orescanin-Dusic Z, Rakocevic Z, Spasic MB, Blagojevic D: Fullerenol $\mathrm{C} 60(\mathrm{OH}) 24$ nanoparticles decrease relaxing effectsof dimethyl sulfoxide on rat uterus spontaneous contraction, J Nanopart Res (2013) 15:1650.

31. Appiah Isabella, Nikolic-Kokic A, Orescanin-Dusic Z, Radojicic R, Milovanovic S, Spasic M, Blagojevic D:Reversible Oxidation ofMyometrial Voltage-Gated Potassium Channels with Hydrogen Peroxide, Oxidative Medicine and Cellular Longevity, 2012, Article ID 105820, 1-7.

32. Milovanovic S.R. Prostran M., Varagic V.M. and Boskovic B. Effect de la nitrendipine sur 1 uterus isole muscles du rat. Soc. Biol., 23, 183-189, 1989. 